\title{
No role for glutathione S-transferase genotypes in Caucasian esophageal squamous cell or adenocarcinoma etiology: an European case-control study
}

\author{
Polat Dura ${ }^{1 *}$, Jody Salomon ${ }^{1}$, Rene HM Te Morsche ${ }^{1}$, Hennie MJ Roelofs ${ }^{1}$, Jon O Kristinsson ${ }^{1}$, Theo Wobbes²,
} Ben JM Witteman ${ }^{3}$, Adriaan CITL Tan ${ }^{4}$, Joost PH Drenth ${ }^{1}$ and Wilbert HM Peters ${ }^{1}$

\begin{abstract}
Background: Identifying and monitoring high-risk patients can aid the prevention of esophageal cancer (EC). The interaction of environmental risk factor exposure and genetic susceptibility may contribute to the etiology of EC. Biotransformation enzymes such as Glutathione S-Transferases (GSTs) detoxify mutagenic and genotoxic compounds and therefore control the rate of detoxification of carcinogens. Functional polymorphisms in the genes coding for GSTs alter their enzyme activity in vitro, and were reported to modify EC risk in Asians. We hypothesized that altered enzyme activity GST genotypes influence the susceptibility for esophageal adeno- (EAC) and squamous cell carcinoma (ESCC) in Caucasians.

Methods: We performed a case-control study including 440 Caucasian patients with EC and 592 healthy Caucasian controls matched for age and sex. Functional polymorphisms were selected and genotypes were determined in GST classes Alpha, Mu, Theta and Pi by means of polymerase chain reaction. Genotypes were classified into predicted high, intermediate and low enzyme activity categories based on in vitro activity data. The distribution of the activity genotypes were compared between patients with EAC or ESCC, and controls. Odds ratios (OR) with 95\% confidence intervals (Cl) were calculated by logistic regression analyses. Gene-gene interactions were tested and for comparison purposes, the predicted low and intermediate activity genotypes were combined. Genotypes with similar risks for EAC or ESCC were combined and analyzed for multiplicative effects.
\end{abstract}

Results: Our analyses includes 327 patients with EAC and 106 patients with ESCC. Low or intermediate activity enzyme genotypes for GSTM1, GSTA1, GSTP1 1105V and A114V as well as for GSTT1, did not significantly modify the risk for ESCC or EAC in our Dutch population.

Conclusion: Functional genotypes in GST genes are not involved in EAC or ESCC susceptibility in Caucasians, in contrast to results on ESCC from Asia or Africa.

\section{Background}

Esophageal Cancer (EC) has limited treatment options resulting in poor 5-year survival rates of $15 \%$ [1] and it holds one of the highest cancer mortality rates [2]. The leading global histological subtype used to be esophageal squamous cell carcinoma (ESCC), but in Western countries a rapid increase in adenocarcinoma has occurred

\footnotetext{
*Correspondence: p.dura@mdl.umcn.nl

'Department of Gastroenterology, Radboud University Nijmegen Medical Center, P.O. Box 9101, 6500 HB, Nijmegen, The Netherlands

Full list of author information is available at the end of the article
}

over the past decennia [3]. To a large extent this development is due to the increase in prevalence of gastroesophageal reflux disease (GERD) and obesity, two significant determinants of esophageal adenocarcinoma (EAC) [3]. Risk factors as smoking and alcohol consumption are significantly related to ESCC and contribute to the still dominating position of this subtype in Asia [3]. Exposure to environmental risk factors alone cannot explain all cases of esophageal carcinoma, genetic predisposition appears to play a role as well. Detoxification enzymes biotransform carcinogens and toxic agents

\section{Biomed Central}

(C) 2013 Dura et al.; licensee BioMed Central Ltd. This is an Open Access article distributed under the terms of the Creative Commons Attribution License (http://creativecommons.org/licenses/by/2.0), which permits unrestricted use, distribution, and reproduction in any medium, provided the original work is properly cited. 
into less active and water-soluble compounds ready for excretion with bile, urine or faeces. The activity of phase I and II enzymes determine the rate of detoxification of carcinogens in cells and tissues.

Glutathione S-transferases (GSTs) are important phase II biotransformation enzymes catalyzing the nucleophilic addition of glutathione to xenobiotics, oxidative stress products and phase I electrophilic and carcinogenic metabolites [4]. Allelic variation in GST genes affects in vivo enzyme activity and subsequently decrease the rate of carcinogen detoxification. The GST family has a widely variable organ distribution and four classes of GSTs; Alpha, $\mathrm{Mu}$, Theta and $\mathrm{Pi}$, are known to have esophageal expression [5]. The high level of esophageal expression, polymorphic nature of the GST genes and the wide range of carcinogenic substrates, make it all very plausible that this superfamily of detoxification enzymes may influence esophageal carcinoma susceptibility.

Many studies addressing this issue originate from Asia and as a result ESCC has been widely studied as summarized in a recent meta-analysis [6]. To a lesser extend EAC cases have been included in studies, along with Barrett's esophagus (BE). BE is suggested to be the histological precursor of EAC, displaying metaplastic columnar epithelium and sharing GERD and obesity as risk factors [7]. It was demonstrated that there is a decreased GST enzyme activity or expression following the sequence; normal esophageal epithelium, Barrett's metaplasia, dysplasia, adenocarcinoma [8,9], suggesting an early etiological role for this enzyme system. Studies examining the role of functional polymorphisms in the GST genes expressed in the esophagus (classes Alpha, $\mathrm{Mu}$, Theta and $\mathrm{Pi}$ ) in relation to EAC risk are lacking. This study was set out to examine whether (combined) GST genotypes with altered predicted enzyme activities, modified EAC and ESCC risk in Caucasians. We conducted a case-control study between 2002 and 2012 on 440 patients with EC and 592 age and sex matched controls of the Caucasian race.

\section{Methods}

\section{Patients with EC and controls}

The study was approved by the Medical Ethical Review Committee, region Arnhem-Nijmegen (CMO 2002/114). From 2002 to March 2012, 349 EDTA blood samples from Caucasian patients with esophageal carcinoma were collected from 4 hospitals within $30 \mathrm{~km}$ distance in the South-East area of the Netherlands [10]. For some EC cases $(n=91)$ no blood was available as source of DNA and in these cases DNA was isolated from normal esophageal or gastric tissue, obtained after surgery [10], so in total 440 EC cases could be evaluated. Patients were included in the order of entry to the hospitals. Also 592 EDTA blood samples from healthy controls, matched as a group for age, Caucasian race, gender and geographical location, were recruited after advertisement in local papers, as described earlier [10]. Only patients with a diagnosis of esophageal carcinoma, as confirmed by a pathologist, were included in the study. Tissue, blood and DNA were stored, and DNA isolation was performed as previously described [11].

\section{Esophageal GST classes and genotyping}

GST classes were selected on the basis of possible relevance to esophageal carcinoma etiology, expression in esophageal mucosa, and significance as revealed in Asian case-control studies on ESCC risk [6]. Only functional polymorphisms were chosen for genotyping, again based on possible relevance for EC susceptibility.

Genotypes as well as the sequences of the primers and probes are depicted in Table 1. The GSTM1 isozyme contains three main genotypes at its locus on chromosome 1p13: GSTM1*a, GSTM1*b and GSTM1*0. GSTM1*a and GSTM11*b differ only at base position 519 by a $\mathrm{G}>\mathrm{C}$ replacement which results in a $\mathrm{K}>\mathrm{N}$ substitution at codon 173. This has no effect on the catalytic properties of the respective enzymes. However, presence of the GSTM1" 0 allele results in a protein absence and homozygosity of GSTM1*0 (GSTM1 null genotype) results in an absence of enzyme activity [4]. The deletion polymorphism was examined through melt curve analysis [12].

The glutathione S-transferase Alpha gene has four functional polymorphisms in full linkage disequilibrium; $-631 \mathrm{~T},-567 \mathrm{~T},-69 \mathrm{C},-52 \mathrm{G}$ designated as allele GSTA1*a and $-631 \mathrm{G},-567 \mathrm{G},-69 \mathrm{~T},-52 \mathrm{~A}$ designated as allele GSTA $1 * b$. Genotypes were determined via the PCR and restriction enzymes methodology as described by Coles et al. [13].

Chromosome 11q13 is the locus for the GSTP1 gene. A base pair $(A>G)$ substitution at nucleotide 313 results in the amino-acid substitution Isoleucine (I) to Valine (V) at codon 105. In addition, the $\mathrm{C}>\mathrm{T}$ substitution at nucleotide 341 creates a change in amino-acid transcription at codon 114: Alanine (A) to Valine (V). The GSTP1 variant alleles express a protein with an altered enzyme activity and substrate specificity [14]. GSTP1 polymorphisms were determined by using the CFX96 Real Time PCR Detection System (Bio-Rad Hercules, CA, USA). DNA samples were amplified by PCR and detection was performed using sequence specific DNA-probes. Primers and probes for detection of the polymorphisms (Table 1) were designed using Beacon designer software (PREMIER Biosoft International, Palo Alto, CA, USA) and synthesized by Sigma Aldrich (St. Louis, MO, USA). For Real Time PCR, the DNA was denatured at $95^{\circ} \mathrm{C}$ for 3 min, followed by 40 cycles of $30 \mathrm{sec}$ at $95^{\circ} \mathrm{C}, 30 \mathrm{sec}$ at annealing temperature (Table 1) and $30 \mathrm{sec}$ elongation at $72^{\circ} \mathrm{C}$. Analysis was performed by the Bio-Rad CFX 
Table 1 Primers and probes and annealing temperatures for detection of GST polymorphisms

\begin{tabular}{|c|c|c|c|c|c|}
\hline GST & $\begin{array}{l}\text { Polymorphism } \\
\text { protein change }\end{array}$ & Genotypes & $\begin{array}{l}\text { Primers (forward) } \\
\text { probes (wild type) }\end{array}$ & $\begin{array}{l}\text { Primer (reverse) } \\
\text { probes (mutant) }\end{array}$ & $\begin{array}{l}\text { Annealing temp. } \\
\mathrm{MgCl}_{2} \text { Conc. }\end{array}$ \\
\hline \multirow[t]{3}{*}{ GSTM1 } & Deletion & Wild Type: GSTM1 + & $\begin{array}{l}\text { 5'-CTC CTG ATT ATG } \\
\text { ACA GAA GCC-3' }\end{array}$ & $\begin{array}{l}\text { 5'-CTG GAT TGT AGC } \\
\text { AGA TCA TGC-3' }\end{array}$ & $58^{\circ} \mathrm{C}$ \\
\hline & Polymorphism & Hetero.: GSTM1 + & & & $2.0 \mathrm{mM}$ \\
\hline & & Homoz: GSTM1 - & & & \\
\hline \multirow[t]{3}{*}{ GSTA1 } & $-631 \mathrm{~T}>\mathrm{G}$ & Wild Type: GSTA $1{ }^{*} a{ }^{*} a$ & $\begin{array}{l}5^{\prime}-\mathrm{TGT} \text { TGA TTG TाT } \\
\text { GCC TGA AAT T-3' }\end{array}$ & $\begin{array}{l}5^{\prime}-\text { GTT AAA CGC TGT } \\
\text { CAC CGT CC-3' }\end{array}$ & $58.5^{\circ} \mathrm{C}$ \\
\hline & $-567 \mathrm{~T}>\mathrm{G}$ & Hetero:: GSTA1 ${ }^{*} a{ }^{*} b$ & & & $2.0 \mathrm{mM}$ \\
\hline & $-69 C>T,-52 G>A$ & Homoz: $G S T A 1{ }^{*} b /{ }^{*} b$ & & & \\
\hline \multirow[t]{3}{*}{ GSTP1 } & $313 A>G$ & Wild Type: I-105-I & $\begin{array}{l}5^{\prime}-C C T \text { GGT GGA CAT } \\
\text { GGT GAA TGA-3' }\end{array}$ & $\begin{array}{l}\text { 5'-AGC CAC CTG AGG } \\
\text { GGT AAG-3' }\end{array}$ & $64^{\circ} \mathrm{C}$ \\
\hline & $105 \mathrm{lle}>\mathrm{Val}$ & Hetero.: I-105-V & $\begin{array}{l}\text { 5'-Fam-CGC TGC AAA } \\
\text { TAC ATC TCC CTC ATC } \\
\text { TAC A-BHQ1-3' }\end{array}$ & $\begin{array}{l}5^{\prime}-H e x-C G C \text { TGC AAA } \\
\text { TAC GTC TCC CTC ATC } \\
\text { TAC A-BHQ1-3' }\end{array}$ & $2.5 \mathrm{mM}$ \\
\hline & & Homoz: $V-105-\mathrm{V}$ & & & \\
\hline \multirow[t]{3}{*}{ GSTP1 } & $341 C>T$ & Wild Type: A-114-A & $\begin{array}{l}5^{\prime}-\text { TGGACAGGCAGAAT } \\
\text { GGAATAGAG }-3^{\prime}\end{array}$ & $\begin{array}{l}\text { 5'- GGGTCTCAAAAGGCT } \\
\text { TCAGTTG -3' }\end{array}$ & $65^{\circ} \mathrm{C}$ \\
\hline & $114 \mathrm{Ala}>\mathrm{Val}$ & Hetero: A-114-V & $\begin{array}{l}\text { 5'-Fam-CATCCTTGCCC } \\
\text { GCCTCCTGCCAGA -BHQ1-3' }\end{array}$ & $\begin{array}{l}\text { 5'-Hex-CATCCTTGCCCACC } \\
\text { TCCTGCCAGA -BHQ1-3' }\end{array}$ & $3.0 \mathrm{~mm}$ \\
\hline & & Homoz: $V-114-V$ & & & \\
\hline \multirow[t]{3}{*}{ GSTT1 } & Deletion & Wild Type: GSTT1 + & $\begin{array}{l}5^{\prime}-T T C \text { CTT ACT GGT } \\
\text { CCT CAC ATC TC-3' }\end{array}$ & $\begin{array}{l}5^{\prime}-\text { TCA CCG GAT CAT } \\
\text { GGC CAG CA-3' }\end{array}$ & $59.5^{\circ} \mathrm{C}$ \\
\hline & Polymorphism & Hetero.: GSTT1 + & & & $2.0 \mathrm{mM}$ \\
\hline & & HomoZ:: GSTT1 - & & & \\
\hline
\end{tabular}

Manager detection software for Windows version 2.0 (Bio-Rad Hercules). The intensity of the mutant probe signal (HEX) was plotted against the wild type probe signal.

The GSTT1 gene is located on chromosome 22q11 and contains 2 variant alleles. The GSTT1*0 allele results in a gene deletion and expresses no enzyme activity, while the wild type allele GSTT1*1 is fully active [15]. The deletion polymorphism was determined via melt curve analysis [15]. However, due to the nature of the polymorphism in GSTM1 and GSTT1, the distinction between heterozygous and homozygous functional genotypes cannot be made by our analyses. Only the homozygous variant genotype (null genotype) can be differentiated.

\section{Statistical analyses}

The independent samples t-test was applied for the differences in continues variables between characteristics of patients and controls. The chi-square test was used for analyzing nominal variables of patient characteristics and to test for differences of frequencies in genotypes between two groups. Logistic regression analyses were used to calculate odds ratios (OR) with 95\% confidence intervals $(95 \% \mathrm{CI})$. Genotypes were classified in predicted enzyme activity groups, and the predicted high enzyme activity group was set as reference. Stratified analyses were performed according to tumor histology.

To test the EC risk interactions of GST genotypes, at first the genotypes with predicted low and intermediate enzyme activity of GSTA1, GSTP1 105 or GSTP1 114 were combined to create two instead of three subgroups: a reference subgroup with predicted high enzyme activity genotypes and a subgroup with predicted low/intermediate enzyme activity genotypes. Then, GST genotypes associated with either a decreased risk $(\mathrm{OR}<1)$ or increased risk $(\mathrm{OR}>1)$ were analyzed for interactions (Figure 1$)$ by logistic regression analyses.

All $\mathrm{P}$ values were two-sided and a probability level of $\mathrm{P}<0.05$ was considered to be significant. All analyses were performed with the software SPSS for Windows, version 20.0 (SPSS Inc., Chicago, IL, USA).

\section{Results}

Table 2 shows the demographics of patients and controls. A total of 440 patients with esophageal cancer, 327 with EAC and 106 with ESCC, and 592 healthy controls were included. For 7 patients the exact tumour type was not mentioned in the pathology reports and these samples were therefore excluded from the histology stratified analyses. Controls were matched with the whole EC 


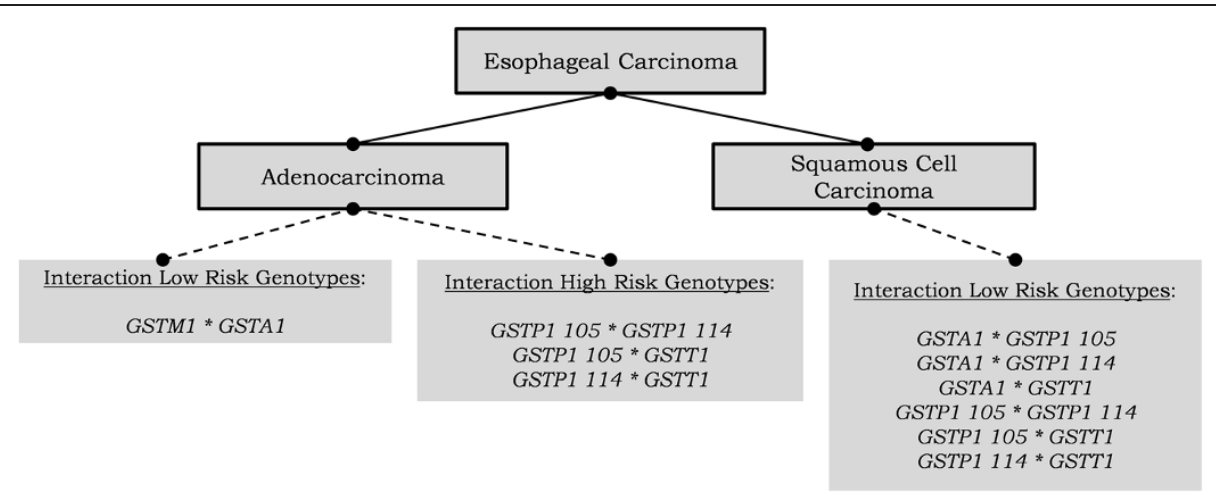

Figure 1 GST genotype combinations. Low risk genotypes: variant genotypes associated with a decreased EAC or ESCC risk (OR $<1.0)$. High risk genotypes: variant genotypes associated with an increased EAC or ESCC risk (OR > 1.0).

patient group for Caucasian ethnicity, recruiting area, age and sex. The female sex was more present in patients with ESCC in comparison to patients with EAC $(\mathrm{P}<0.001)$, and in comparison to controls $(\mathrm{P}=0.003)$. Otherwise, no significant difference was found between the reported demographics of patients with EAC or ESSC, and controls.

Genotypes were analyzed for both the histological subgroups in comparison to controls and classified into predicted enzyme activity groups (Table 3). GSTA1 and GSTP1 polymorphisms were distributed according to the Hardy-Weinberg equilibrium (GSTA1 controls/cases, $\mathrm{P}=$ $0.71 / \mathrm{P}=0.38 ;$ GSTP1-I105V controls/cases, $\mathrm{P}=0.27 / \mathrm{P}=$ 0.79; GSTP1-A114V controls/cases, $\mathrm{P}=0.75 / \mathrm{P}=0.97$ ).

Table 4 depicts the odds ratios for the comparisons of groups with predicted enzyme activity between patients with ESCC or EAC, and controls. For GSTM1, GSTA1, GSTP1 I105V and A114V as well as for GSTT1, the low or intermediate activity enzyme genotypes did not significantly modify the risk for ESCC or EAC in our population.

The (combined) genotypes of predicted low and low/ intermediate enzyme activity (see Table 3 ) were analyzed for interactions, when genotypes had similar effect sizes (decreased or increased risk). For example, the correlation

Table 2 Characteristics of patients and controls

\begin{tabular}{lllll}
\hline Characteristics & Patients & & \multicolumn{1}{c}{ Controls } \\
\hline & ESCC & EAC & EC & \\
Number $(\%)$ & $106^{*}(24.1 \%)$ & $327^{*}(74.3 \%)$ & $440^{*}(100 \%)$ & 592 \\
$\begin{array}{l}\text { Age } \\
\text { (yrs; mean } \pm \text { SD) }\end{array}$ & $64.4 \pm 10.5$ & $64.9 \pm 11.2$ & $64.8 \pm 11.1$ & $63.4 \pm 11.9$ \\
Gender & & & & \\
$\quad$ Male & $67^{*}(63.2 \%)$ & $281(85.9 \%)$ & $348(79.0 \%)$ & $478(80.7 \%)$ \\
$\quad$ Female & $38^{*}(35.8 \%)$ & $46(14.1 \%)$ & $84(19.1 \%)$ & $114(19.3 \%)$ \\
\hline
\end{tabular}

*Note that for 7 patients data on the exact tumor type are missing, whereas for 1 patient the gender is unknown.

ESSC esophageal squamous cell carcinoma, EAC esophageal adenocarcinoma. between the combined genotypes of GSTM1 \& GSTA1 was analyzed because the predicted low enzyme activity genotypes of GSTM1 or low/intermediate genotypes of GSTA1 both showed an OR $<1$ for EAC risk (see Table 4 and Figure 1). Only the correlation of predicted low/intermediate enzyme activity genotypes GSTP1 105 and GSTA1 $(P<0.05)$ and GSTP1 105 and GSTT1 $(P=0.053)$ showed a significant and near significant lower risk for ESCC, respectively. The genotypes of predicted low and intermediate GSTP1 105 \& low and intermediate GSTA1 enzyme activity, and of low and intermediate GSTP1 105 \& low GSTT1 were combined and set off against their corresponding predicted high activity genotypes, but the associations for ESCC risk failed to reach significance; OR 0.62 ; $95 \%$ CI $0.36-1.08$ and $0.46 ; 0.20-1.07$, respectively (Figure 2).

\section{Discussion}

This case-control study reveals no associations between modified activity GST genotypes and EAC or ESCC susceptibility in Caucasians. Only GSTA1 low or intermediate genoytpe was associated with a non-significant protective effect for both tumour types, whereas the remaining GST classes showed contradictory effect sizes for EAC and ESCC.

Although many case-control studies investigated GST polymorphisms and EC risk, only seven originated from Western populations and reported on EAC risk. These studies were from Europe [16-19], the USA [20] and Canada $[21,22]$. Our results contrasts with the findings of Casson et al. [21] and Abbas et al. [16] that the GSTP1 Ile105 Val and GSTT1*1*1 genotype increased EAC risk, ORs are 2.5; $1.0-6.3$ and 13.3; $1.7-106.9$, respectively. Furthermore van Lieshout et al. [18] and Zendehdel et al. [19] reported on both ESCC and EAC susceptibility and found the GSPP1 variant allele to increase the risk for EAC and ESCC, respectively. However, all studies offer inconclusive results due to very low number of EAC and ESCC cases 
Table 3 GST genotype distribution according to predicted enzyme activity

\begin{tabular}{|c|c|c|c|c|c|}
\hline GST & GST genotypes & Predicted enzyme activity & $\operatorname{ESCC}(n=106) \#$ & EAC $(n=327) \#$ & Controls $(n=592) \#$ \\
\hline \multirow[t]{2}{*}{ GST M1 } & ${ }^{*} 1 /{ }^{*} 1 \& *^{*} 1 /{ }^{*} 0$ & High-Intermediate & $48(45.7 \%)$ & $156(47.7 \%)$ & $273(46.2 \%)$ \\
\hline & ${ }^{*} 0 /{ }^{*} 0$ & Low & $57(54.3 \%)$ & $171(52.3 \%)$ & $318(53.8 \%)$ \\
\hline \multirow[t]{3}{*}{ GST A1 } & ${ }^{*} 1 a{ }^{*} 1 a$ & High & $43(41.3 \%)$ & $131(42.1 \%)$ & $214(37.2 \%)$ \\
\hline & $* 1 a{ }^{*} 1 b$ & Intermediate & $50(48.1 \%)$ & $133(42.8 \%)$ & $277(48.2 \%)$ \\
\hline & $* 1 b / * 1 b$ & Low & $11(10.6 \%)$ & $47(15.1 \%)$ & $84(14.6 \%)$ \\
\hline \multirow[t]{3}{*}{ GST P1 I105V } & He / lle & High & $48(45.7 \%)$ & 119 (37.5\%) & $246(41.6 \%)$ \\
\hline & Ile / Val & Intermediate & $42(40.0 \%)$ & $157(49.5 \%)$ & $261(44.2 \%)$ \\
\hline & Val / Val & Low & $15(14.3 \%)$ & $41(12.9 \%)$ & $84(14.2 \%)$ \\
\hline \multirow[t]{3}{*}{ GST P1 $\underline{\text { A114V }}$} & Ala / Ala & High & $92(86.8 \%)$ & $262(82.6 \%)$ & $485(83.5 \%)$ \\
\hline & Ala / Val & Intermediate & $14(13.2 \%)$ & $52(16.4 \%)$ & $91(15.7 \%)$ \\
\hline & $\mathrm{Val} / \mathrm{Val}$ & Low & 0 & $3(0.9 \%)$ & $5(0.9 \%)$ \\
\hline \multirow[t]{2}{*}{ GST T1 } & $*^{*} /{ }^{*} 1 \& * 1 / *^{*}$ & High-Intermediate & $87(82.9 \%)$ & 248 (75.8\%) & $463(78.3 \%)$ \\
\hline & ${ }^{*} 0 /{ }^{*} 0$ & Low & $18(17.1 \%)$ & 79 (24.2\%) & $128(21.7 \%)$ \\
\hline
\end{tabular}

ESSC esophageal squamous cell carcinoma, EAC esophageal adenocarcinoma. \#Some genotyping data were missing due to PCR bias.

$(n<100)$, except for the study of Murphy et al. which included 207 EAC cases [17]. Our study includes a relatively large EAC group and consequently may offer a higher power.

Although there is a degree of inconsistency and population sizes are relatively small $(n=45$ and $n=234$ $[23,24])$, ESCC risk is generally addressed by Asian studies and reported increasing ESCC risk for the homozygous GSTP1105 Val and homozygous GSTM1*0 genotypes whereas some studies even conclude them to be independent risk factors for ESCC in China [25-27] and Brazil [28]. The largest studies however $(n=562 \&$

Table 4 Odds ratios and $95 \% \mathrm{Cl}$ according to predicted GST enzyme activity genotypes for ESCC and EAC patients compared to controls

\begin{tabular}{|c|c|c|c|}
\hline GST & Comparisons & ESCC OR $(95 \% \mathrm{Cl})^{*}$ & EAC OR $(95 \% \mathrm{Cl})$ \\
\hline \multirow[t]{2}{*}{ GST M1 } & High- Intermediate & Ref & Ref \\
\hline & Low & $1.06(0.69-1.61)$ & $0.94(0.72-1.23)$ \\
\hline \multirow[t]{3}{*}{ GST A1 } & High & Ref & Ref \\
\hline & Intermediate & $0.88(0.56-1.38)$ & $0.78(0.58-1.06)$ \\
\hline & Low & $0.58(0.28-1.21)$ & $0.91(0.60-1.39)$ \\
\hline \multirow{3}{*}{$\begin{array}{l}\text { GST } \\
\text { P1/105V }\end{array}$} & High & Ref & Ref \\
\hline & Intermediate & $0.83(0.53-1.29)$ & $1.24(0.93-1.67)$ \\
\hline & Low & $0.92(0.49-1.72)$ & $1.01(0.66-(1.56)$ \\
\hline \multirow{3}{*}{$\begin{array}{l}\text { GST } \\
\text { P1A114V }\end{array}$} & High & Ref & Ref \\
\hline & Intermediate & $0.86(0.47-1.59)$ & $1.06(0.73-1.54)$ \\
\hline & Low & & $1.11(0.26-4.68)$ \\
\hline \multirow[t]{2}{*}{ GST T1 } & High-Intermediate & Ref & Ref \\
\hline & Low & $0.80(0.46-1.39)$ & $1.15(0.84-1.59)$ \\
\hline
\end{tabular}

* Odds ratios were adjusted for gender.

ESSC esophageal squamous cell carcinoma, EAC esophageal adenocarcinoma. $\mathrm{n}=245 ; \quad[29,30])$, originated from South Africa with conflicting results, as mixed ancestry in African populations are a difficulty for genetic investigators. So although results differ globally, our finding is in accordance with several meta-analyses [6,31-33], concluding that GST genotypes do not seem EC risk factors, the variant GSTP1 105 genotypes excluded [33]. Zendehdel et al. conducted a Swedish case-control study as well as a meta-analysis, including only studies with Caucasians, and stratified according to histology [19]. Interestingly, this meta-analysis consisted of the Caucasian studies mentioned above [16-18,20-22] and found that the GSTP1 $I 105 \mathrm{~V}$ polymorphism was associated with an increased risk for $\operatorname{ESCC}(1.4 ; 1.0$ - 2.2) and not for EAC (1.2; 0.9 - 1.6). However, their own data contributed largely to this effect, as their patient numbers consisted $60 \%$ of the pooled numbers of the meta analysis.

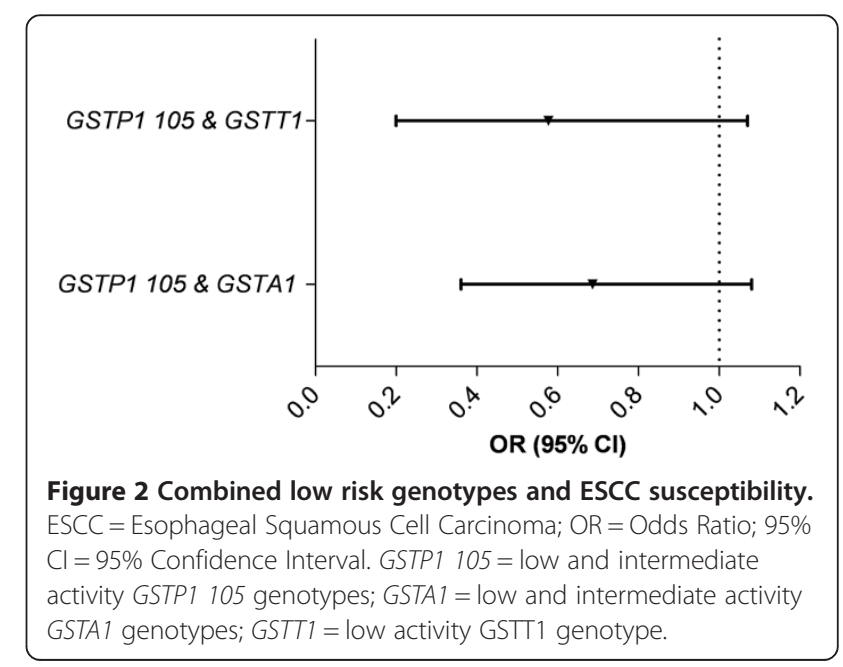


So according to the literature so far, only the GSTP1 Ile105 Val polymorphism seems involved in ESCC etiology. Our genotype-genotype interaction analyses confirmed this premise, as combinations of low and intermediate GSTA1, or low GSTT1, with low and intermediate GSTP1 105 genotypes showed a trend for a decreased ESCC risk. Other studies on interactions mostly examined the GSTM1 null genotype in combination with either CYP2E1 $[25,26,34]$ or CYP1A1 genotypes [27]. Moaven et al. reported that interactions between GST polymorphisms were not associated with a modifying effect for ESCC in an Iranian population [35], while Wang et al. reached similar conclusions in a Chinese cohort [36]. Both studies however had small patient numbers ( $n=148$ and $n=107$, respectively). Larger study sizes are warranted to investigate the effect of combined GST genotypes, more explicitly combinations with GSTP1 genotypes, and the risk for ESCC. Moreover, GSTP1 is the main GST enzyme expressed in the esophagus [9] and the genetic variants express proteins with a large reduction of enzyme activity [37].

Another important finding clearly depicted by this study, is the contrasting effects for ESCC and EAC risk, possibly related to their different etiologies. An increasing risk for EAC by GST genotypes may be due to a lower detoxification rate of carcinogens. But studies originating from South Africa [30] and Iran [38] correspond with our results and also report protective effect sizes of GST variants for ESCC risk. Matejic et al. explains this by the prevention of glutathione (GSH) depletion, due to a decreased conjugation activity of the GSTs. GSH is a powerful antioxidant and thus an optimal GSH level to protect against oxidants is maintained [30]. However, it remains difficult to clarify the difference in effect size between EAC and ESCC. Substrate overlap between GST isozymes can compensate the decreased detoxification of mutagens attributable to a single enzyme deficiency. Moreover, the risk for EAC and ESCC is probably substrate dependent. Although substrate overlapping occurs for oncogenetic compounds such as Benzo A-Pyrene-Diol-Epoxide, 1,2-epoxy-3-butene and 1,2:3,4diepoxybutane, there is a degree of specificity per GST isoenzyme. The Mu, Alpha and Pi GSTs conjugate several carcinogenic epoxides like aflatoxin B1 epoxide (a naturel carcinogen) and polycyclic aromatic hydrocarbons diol epoxide such as benzo[a]pyrene (BaP). The Theta class GST is involved in the detoxification of small dihaloalkanes such as dichloromethane which is an important compound used in paint strippers, plastics and pharmaceutical drugs, and also dibromoethane, an anti-knocking agent in gasoline.

Limitation of our study are the relatively small number of cases involved, which after stratification according to tumor histology, results in even lower subgroup numbers and therefore limits the power of the study. For instance, interactions with the GSTP1 variants showed a tendency to modify ESCC risk, but genotype combinations failed to reach statistical significance, which mainly may be a power issue as the especially the ESCC group is small in our Dutch Caucasian population. Another limitation is the lack of data on exposure to mutagenic compounds (smoking, alcohol consumption, etc.) in patients and controls, to counterbalance confounding effects (and additionally examine potential gene-environment effects).

\section{Conclusion}

We conducted the largest case-control study so far on GST variant genotypes and esophageal cancer risk in a Western population of Caucasian ethnicity. Although this study did not detect significant associations between altered predicted enzyme activity GST genotypes and EAC or ESCC risk, our results indicate that gene-gene interactions between GSTP1 variants could play a role in EC susceptibility.

\section{Competing interests}

The authors declare that they have no competing interests.

\section{Authors' contributions}

PD, JPHD and WHMP designed the study. PD, JS, RHMtM, HMJR, JOK, TW, BJMW, ACITLT and WHMP were involved in acquisition, analysis and interpretation of data. PD and WHMP drafted the manuscript, which was critically revised by JS, RHMtM, HMJR, JOK, TW, BJMW, ACITLT and JPHD. All authors read and approved the final manuscript.

\section{Acknowledgement}

P. Dura was financially supported by BBMRI-NL, a Research Infrastructure financed by the Dutch government (NWO 184.021.007; grants CP 28 and (P2011-02)

\section{Author details}

'Department of Gastroenterology, Radboud University Nijmegen Medical Center, P.O. Box 9101, 6500 HB, Nijmegen, The Netherlands. ²Department of Surgery, Radboud University Nijmegen Medical Center, Nijmegen, The Netherlands. ${ }^{3}$ Department of Gastroenterology, Hospital Gelderse Vallei, Willy Brandtlaan 10, 6717, RP Ede, The Netherlands. ${ }^{4}$ Deparment of Gastroenterology, Canisius-Wilhelmina Hospital, Weg door Jonkerbos 100, 6532 SZ, Nijmegen, The Netherlands.

Received: 15 February 2013 Accepted: 22 May 2013

Published: 3 June 2013

\section{References}

1. Sant M, Aareleid T, Berrino F, Bielska Lasota M, Carli PM, Faivre J, Grosclaude P, Hedelin G, Matsuda T, Møller H, Möller T, Verdecchia A, Capocaccia R, Gatta G, Micheli A, Santaquilani M, Roazzi P, Lisi D: EUROCARE Working Group: EUROCARE-3: survival of cancer patients diagnosed 1990-94-results and commentary. Ann Oncol 2003, 14(Suppl 5):v61-v118.

2. Wijnhoven BP, Louwman MW, Tilanus HW, Coebergh JW: Increased incidence of adenocarcinomas at the gastro-oesophageal junction in Dutch males since the 1990s. Eur J Gastroenterol Hepatol 2002, 14:115-122.

3. Hongo M, Nagasaki Y, Shoji T: Epidemiology of esophageal cancer: Orient to Occident. Effects of chronology, geography and ethnicity. J Gastroenterol Hepatol 2009, 24:729-735.

4. Hayes JD, Strange RC: Glutathione S-transferase polymorphisms and their biological consequences. Pharmacology 2000, 61:154-166.

5. Van Lieshout EMM, Tiemessen DM, Witteman BJM, Jansen JBMJ, Peters WHM: Low glutathione and glutathione S-transferase levels in Barrett's esophagus as compared to normal esophageal epithelium. Jpn J Cancer Res 1999, 90:81-85. 
6. Zhuo WL, Zhang YS, Wang Y, Zhuo XL, Zhu B, Cai L, Chen ZT: Association studies of CYP1A1 and GSTM1 polymorphisms with esophageal cancer risk: evidence-based meta-analyses. Arch Med Res 2009, 40:169-179.

7. Shaheen N, Ransohoff DF: Gastroesophageal reflux, barrett esophagus, and esophageal cancer: scientific review. JAMA 2002, 287:1972-1981.

8. Herszenyi L, Hritz I, Pregun I, Sipos F, Juhasz M, Molnar B, Tulassay Z: Alterations of glutathione S-transferase and matrix metalloproteinase- 9 expressions are early events in esophageal carcinogenesis. World J Gastroenterol 2007, 13:676-682.

9. Peters WHM, Roelofs HMJ, Hectors MP, Nagengast FM, Jansen JBMJ: Glutathione and glutathione S-transferases in Barrett's epithelium. $\mathrm{Br} J$ Cancer 1993, 67:1413-1417.

10. Kristinsson JO, Van Westerveld P, Te Morsche RHM, Roelofs HMJ, Wobbes T, Witteman BJM, Tan ACITL, Van Oijen MG, Jansen JBMJ, Peters WHM: Cyclooxygenase-2 polymorphisms and the risk of esophageal adeno- or squamous cell carcinoma. World J Gastroenterol 2009, 15:3493-3497.

11. Dura P, Salomon J, Te Morsche RHM, Roelofs HMJ, Kristinsson JO, Wobbes T, Witteman BJM, Tan ACITL, Drenth JPH, Peters WHM: High enzyme activity UGT1A1 or low activity UGT1A8 and UGT2B4 genotypes increase esophageal cancer risk. Int Oncol 2012, 40:1789-1796.

12. Brockmoller J, Kerb R, Drakoulis N, Nitz M, Roots I: Genotype and phenotype of glutathione S-transferase class mu isoenzymes mu and psi in lung cancer patients and controls. Cancer Res 1993, 53:1004-1011.

13. Coles BF, Morel F, Rauch C, Huber WW, Yang M, Teitel CH, Green B, Lang NP, Kadlubar FF: Effect of polymorphism in the human glutathione Stransferase A1 promoter on hepatic GSTA1 and GSTA2 expression. Pharmacogenetics 2001, 11:663-669.

14. Watson MA, Stewart RK, Smith GB, Massey TE, Bell DA: Human glutathione S-transferase P1 polymorphisms: relationship to lung tissue enzyme activity and population frequency distribution. Carcinogenesis 1998, 19:275-280

15. Pemble S, Schroeder KR, Spencer SR, Meyer DJ, Hallier E, Bolt HM, Ketterer B, Taylor JB: Human glutathione S-transferase theta (GSTT1): cDNA cloning and the characterization of a genetic polymorphism. Biochem J 1994, 300:271-276.

16. Abbas A, Delvinquiere K, Lechevrel M, Lebailly P, Gauduchon P, Launoy G, Sichel F: GSTM1, GSTT1, GSTP1 and CYP1A1 genetic polymorphisms and susceptibility to esophageal cancer in a French population: different pattern of squamous cell carcinoma and adenocarcinoma. World J Gastroenterol 2004, 10:3389-3393.

17. Murphy SJ, Hughes AE, Patterson CC, Anderson LA, Watson RG, Johnston BT, Comber H, McGuigan J, Reynolds JV, Murray LJ: A population-based association study of SNPs of GSTP1, MnSOD, GPX2 and Barrett's esophagus and esophageal adenocarcinoma. Carcinogenesis 2007, 28:1323-1328.

18. Van Lieshout EMM, Roelofs HMJ, Dekker S, Mulder CJ, Wobbes T, Jansen JBMJ, Peters WHM: Polymorphic expression of the glutathione Stransferase P1 gene and its susceptibility to Barrett's esophagus and esophageal carcinoma. Cancer Res 1999, 59:586-589.

19. Zendehdel K, Bahmanyar S, McCarthy S, Nyren O, Andersson B, Ye W: Genetic polymorphisms of glutathione S-transferase genes GSTP1, GSTM1, and GSTT1 and risk of esophageal and gastric cardia cancers. Cancer Causes Control 2009, 20:2031-2038.

20. Wideroff L, Vaughan TL, Farin FM, Gammon MD, Risch H, Stanford JL, Chow WH: GST, NAT1, CYP1A1 polymorphisms and risk of esophageal and gastric adenocarcinomas. Cancer Detect Prev 2007, 31:233-236.

21. Casson AG, Zheng Z, Chiasson D, MacDonald K, Riddell DC, Guernsey JR, Guernsey DL, McLaughlin J: Associations between genetic polymorphisms of Phase I and II metabolizing enzymes, p53 and susceptibility to esophageal adenocarcinoma. Cancer Detect Prev 2003, 27:139-146.

22. Casson AG, Zheng Z, Porter GA, Guernsey DL: Genetic polymorphisms of microsomal epoxide hydroxylase and glutathione S-transferases M1, T1 and P1, interactions with smoking, and risk for esophageal (Barrett) adenocarcinoma. Cancer Detect Prev 2006, 30:423-431.

23. Lin DX, Tang YM, Peng Q, Lu SX, Ambrosone CB, Kadlubar FF: Susceptibility to esophageal cancer and genetic polymorphisms in glutathione $\mathrm{S}$ transferases T1, P1, and M1 and cytochrome P450 2E1. Cancer Epidemiol Biomarkers Prev 1998, 7:1013-1018.

24. Yokoyama A, Kato H, Yokoyama T, Tsujinaka T, Muto M, Omori T, Haneda T, Kumagai $Y$, Igaki H, Yokoyama M, Watanabe $H$, Fukuda $H$, Yoshimizu $H$ : Genetic polymorphisms of alcohol and aldehyde dehydrogenases and glutathione S-transferase M1 and drinking, smoking, and diet in Japanese men with esophageal squamous cell carcinoma. Carcinogenesis 2002, 23:1851-1859.

25. Lu XM, Zhang YM, Lin RY, Arzi G, Wang X, Zhang YL, Zhang Y, Wang Y, Wen $\mathrm{H}$ : Relationship between genetic polymorphisms of metabolizing enzymes CYP2E1, GSTM1 and Kazakh's esophageal squamous cell cancer in Xinjiang, China. World J Gastroentero/ 2005, 11:3651-3654.

26. Tan W, Song N, Wang GQ, Liu Q, Tang HJ, Kadlubar FF, Lin DX: Impact of genetic polymorphisms in cytochrome P450 2E1 and glutathione Stransferases $\mathrm{M} 1, \mathrm{~T} 1$, and $\mathrm{P} 1$ on susceptibility to esophageal cancer among high-risk individuals in China. Cancer Epidemiol Biomarkers Prev 2000, 9:551-556.

27. Wang AH, Sun CS, Li LS, Huang JY, Chen QS: Relationship of tobacco smoking CYP1A1 GSTM1 gene polymorphism and esophageal cancer in Xi'an. World J Gastroenterol 2002, 8:49-53.

28. Rossini A, Rapozo DC, Soares Lima SC, Guimaraes DP, Ferreira MA, Teixeira R, Kruel CD, Barros SG, Andreollo NA, Acatauassu R, Matos HJ, Albano RM, Pinto LF: Polymorphisms of GSTP1 and GSTT1, but not of CYP2A6, CYP2E1 or GSTM1, modify the risk for esophageal cancer in a western population. Carcinogenesis 2007, 28:2537-2542.

29. Li D, Dandara C, Parker Ml: The 341C/T polymorphism in the GSTP1 gene is associated with increased risk of oesophageal cancer. BMC Genet 2010, 11:47.

30. Matejcic M, Li D, Prescott NJ, Lewis CM, Mathew CG, Parker MI: Association of a deletion of GSTT2B with an altered risk of oesophageal squamous cell carcinoma in a South African population: a case-control study. PLOS One 2011, 6:e29366.

31. Zhao Y, Wang F, Shan S, Zhao Y, Qiu X, Li X, Jiao F, Wang J, Du Y: Genetic polymorphism of p53, but not GSTP1, is association with susceptibility to esophageal cancer risk - a meta-analysis. IntJ Med Sci 2010, 7:300-308.

32. Yang CX, Matsuo K, Wang ZM, Tajima K: Phase I/II enzyme gene polymorphisms and esophageal cancer risk: a meta-analysis of the literature. WorldJ Gastroenterol 2005, 11:2531-2538.

33. Bull LM, White DL, Bray M, Nurgalieva Z, El-Serag HB: Phase I and II enzyme polymorphisms as risk factors for Barrett's esophagus and esophageal adenocarcinoma: a systematic review and meta-analysis. Dis Esophagus 2009, 22:571-587.

34. Morita S, Yano M, Shiozaki H, Tsujinaka T, Ebisui C, Morimoto T, Kishibuti M, Fujita J, Ogawa A, Taniguchi M, Inoue M, Tamura S, Yamazaki K, Kikkawa N, Mizunoya S, Monden M: CYP1A1, CYP2E1 and GSTM1 polymorphisms are not associated with susceptibility to squamous-cell carcinoma of the esophagus. Int J Cancer 1997, 71:192-195.

35. Moaven O, Raziee HR, Sima HR, Ganji A, Malekzadeh R, A'Rabi A, Abdollahi A, Memar B, Sotoudeh M, Naseh H, Nekoui N, Razavipour A, Gholamin M, Dadkhah E, Farshchian M, Abbaszadegan MR: Interactions between Glutathione-S-Transferase M1, T1 and P1 polymorphisms and smoking, and increased susceptibility to esophageal squamous cell carcinoma. Cancer Epidemiol 2010, 34:285-290.

36. Wang Z, Tang L, Sun G, Tang Y, Xie Y, Wang S, Hu X, Gao W, Cox SB, Wang JS: Etiological study of esophageal squamous cell carcinoma in an endemic region: a population-based case control study in Huaian China. BMC Cancer 2006, 6:287.

37. Pandya U, Srivastava SK, Singhal SS, Pal A, Awasthi S, Zimniak P, Awasthi YC, Singh SV: Activity of allelic variants of Pi class human glutathione Stransferase toward chlorambucil. Biochem Biophys Res Commun 2000, 278:258-262.

38. Sharifi R, Allameh A, Biramijamal F, Mohammadzadeh SH, Rasmi Y, Tavangar SM, Jamali-Zavarei M: Relationship between genetic polymorphism of glutathione S-transferase-p1 and p53 protein accumulation in Iranian esophageal squamous cell carcinoma patients. Indian J Cancer 2008, 45:8-12.

doi:10.1186/1471-230X-13-97

Cite this article as: Dura et al:: No role for glutathione S-transferase genotypes in Caucasian esophageal squamous cell or adenocarcinoma etiology: an European case-control study. BMC Gastroenterology 2013 13:97. 